\title{
Conditions for Cooperating and Dialogue through the Utilization of Technology in Online Education
}

\author{
Monica J. Lervik*, Tone Vold, Stig Holen \\ Department of Business Administration and Social Sciences, the Inland Norway University of Applied Sciences, Rena, Norway
}

Copyright $\mathrm{O} 2018$ by authors, all rights reserved. Authors agree that this article remains permanently open access under the terms of the Creative Commons Attribution License 4.0 International License

\begin{abstract}
Students learn best when they are active and engaged. Even when we combine asynchronous and synchronous communication, it is challenging to get the optimal levels of engagement and communication. A number of different ways of creating communication and interactivity have been tested out including mandatory on-campus seminars, small size groups of students, video conferencing with chat and teaching in real time. This paper presents a holistic approach to increase communication and engagement in online teaching by using the blended learning concept. The paper presents three different types of network models that combine synchronous and asynchronous communication. The methodological approach is mainly qualitative. The empirical data is mainly interviews and observations. The respondents are lectures who are teaching online. The theory this research rests on is theory on communication and relevant theory about online teaching. Findings and results are from Lervik's PhD work. The results show that the following conditions promote communication, dialogue and engagement in online teaching: compulsory campus meetings before starting online teaching, having small groups of students online, communicating through video conferencing with chat and teaching in true time. Blended learning will in this case be a combination of synchronous and asynchronous communication. The main findings of this research are that these lecturers conduct online education through three different network models. These three web network models vary with the aim of facilitating the flexibility of online students that combine work and study. A critical factor is to conduct on-campus seminars at the start of the education as this enables the teacher and students to get to know each other and develop the trust required to have the required involvement, engagement and communication. A high level of involvement and engagement will increase the learning outcome from the subsequent online teaching. The blend of learning opportunities provides the students with different approaches that can support different learning styles.
\end{abstract}

Keywords Blended Learning, Communication,
Dialogue, Interactivity, Flexibility, Asynchronous and Synchronous Communication

\section{Introduction}

Activating student is recognized as important for students learning, and different takes as e.g. Flipped Classroom, is being used to engage students in order to enhance the learning outcome, but also to keep students motivated so that they finish their studies. Online studies still struggle with high dropout rates, hence the need for finding ways to keep the students in a study and thereby reduce the dropout rate [1]. These efforts will also benefit blended learning courses.

At the Norway Inland University of Applied Sciences, there are three major types of courses: only online, online and seminar based, and on campus courses. We need to meet the requirements from the students, their future (and/or present) employers and the public, and we need to reduce the dropout rate to a minimum due to a financial system that release the financial cost of the student when the student has completed. At the same time, we need to keep the quality of the education at a high standard to fill our obligations as a university. Hence, the constant search of an optimal adaption regarding lecturing and teaching ways.

The research done by Monica Lervik indicates that factors like face-to-face meetings, group size, teaching in real time and communicating through video conferencing with chat and teaching in real/true time are important to the quality of online teaching. Furthermore, the research suggests an opening seminar that is a face-to-face meeting with students and faculty staff in the beginning of a study period. Findings in this research shows three different network models that combine synchronous and asynchronous communication in different ways. Model 1 uses only asynchronous communication, model 2 and the hybrid network model use asynchronous and synchronous 
communication. The three online models for online teaching facilitate different levels of activity, engagement and communication in online education.

Our research question is thus:

How do the three different web models combine asynchronous and synchronous communication?

In this paper, we present some theories that have guided us in our search for increasingly better learning outcome for our students. We also present our research and our results so far.

\section{Theoretical Backdrop for the Study}

Blended learning refers to a way of teaching that embraces three different types of communicating the learning material [2]. It may be a combination of streaming video, teaching in real/true time, online discussion, email conversations, etc.

In online courses, it is important to adapt to the medium. Salmon's five stage model [3] describes a five stage process for how to support and activate students in a digital learning environment. The process promotes cooperation between students and teachers and aims to establish a safe and productive climate that promotes learning. Salmon describes the steps necessary to ensure that the students and the teachers can form an environment that lays the grounds for an optimal learning environment. These elements should be presented to obtain effective learning via technology. The activities during online teaching, which are claimed by Salmon [4] are the most important for the learning outcome. The interaction and the cooperation between the lecturer and students, and amongst the students, need preparation in beforehand. The five stages are:

Stage 1: "Access and motivation": lecturer is to assure that the students have access to the web-based tools and that they receive correct training.

Stage 2: "Online socialization": lecturer must have planned and designed the web-based course that is adapted to online learning

Stage 3: "Information exchange": the most important step as this is where all the students come together and are to claim a role in the cooperation, being able to participate actively in discussions, dialogues and to exchange information

Stage 4: "Knowledge construction": it is important that the students work together and are active in co-constructing the knowledge.

Stage 5: "Development": upon reaching step 5, the students have explored their own thoughts and co-constructed new knowledge. This development is then what we can call the learning outcome.

Flexibility is about how information and communication technology in teaching and dissemination provides increased flexibility and accessibility by making less education dependent on time and place. According to Larsen [5], flexibility for increased accessibility is relative to time and place of study. That is, adapting study plans to students' life situations through the use of ICT so that students can combine studies with work and family life. According to Flate Paulsen [6], it will be designing a flexible subject tailored to the student who will study online will be a critical factor for success in online education

Understanding a language or an intellectual tool is vital in a social-cultural perspective on learning and development [7]. A tool means 'the language, (or intellectual) and physical resources which we have access to and which we use when understanding our surrounding world and reacting in it'[8], [9]. According to Wertsch [10], people learn through participating in communicative and practical interaction with others.

A tool is, according to Wertsch [11] for example, human thought, communication and action that builds on the use of different types of aids. These tools do according to Bliss et al. [4] mediate (communicate) the outside world to people. Mediating means that the world is interpreted through tools which are in turn rooted in a social practice. Learning takes place through language and through participation in social practice. This perspective also emphasizes the social frameworks around peoples' actions.

Language is a means of communication between parties in social interaction [12]. Vygotsky differentiates between a child's spontaneous and everyday concepts developed in interaction with others and scientific terms which are a part of a concept system and which is mediated through education and learning in schools [13] . Scientific terms are learnt in schools through processes rooted in social interaction. It is therefore important to facilitate for interplay and social interaction in courses so that students can reflect upon everyday thinking. Development is an active process, which can be influenced by a teacher and by training [13]. Tools play a major role in all human activity. Intellectual and physical tools use the person to understand the surrounding world. This activity must be studied within the frameworks of human interaction, and with the use of cultural tools (Ibid). A mediated activity is important in this context; an activity being mediated (communicated) using a tool which is developed to carry out the activity. It is, however, first important to learn to use the tool, which one does together with others. Once one has learnt to use it, then one has also acquired the activity the tool is intended for. Intellectual and the physical tools help the person to understand the surrounding world.

Bråten [14] states that intellectual tools are mental, language or discursive tools. These tools contain knowledge and mediate reality to us. We use language tools when we solve problems, discuss with others and carry out actions [8] and we become thinking people through acquiring intellectual tools. When people tell their innermost thoughts and feelings, they communicate using 
concepts and terms, which they have learnt.

Physical tools involve the construction and use of physical tools or artefacts [8]. Bliss et al. [15] state that people have recreated their way of living and have therefore changed their knowledge and activities through creating artefacts. Physical tools are the tools people use upon the surroundings.

According to socio-cultural theory, language is a tool that is unique to human knowledge building and to being able to communicate experiences between people. Words and language mediate the surrounding world to us and make the surrounding world around meaningful to us. We are, through communication with others, able to explain and describe the world around us and interact with others in different activities [8]. It is language that we use as a communication tool to interact with others and share experiences. People use language to interpret and understand the experiences they have together with others. Interacting with others means that you learn to use cultural tools, learning and development through this taking place [8]. Cultural knowledge is transformed via the social experiences of people interacting with others. This experience is furthermore converted to own knowledge and understanding [8].

Vygotsky [16] claimed that the language of thought is first developed as external speech in the social interplay with other people, then differentiated into dialogue speech and monologue speech, or inner speech. This means that the language of thought of a person is developed first in the social (external) arena, language of thought then being made private (inner) (Ibid). We build up knowledge created by others when we participate in interaction with others. One learns to use this knowledge and to link meaning to knowledge through interacting and fellowship. The tools which are used in a teaching situation will be a part of that which is taught. Different ways of interacting are therefore also important tools, which must be learnt.

Vygotsky [17] used the term the zone of proximal development. This is the place where a person, through interaction with others with more experience, acquires new knowledge. It is the zone for potential learning between what a person can manage to do on their own without help (actual development level) and what they can achieve with the guidance of others or in cooperation with others who have more knowledge than they do (potential development

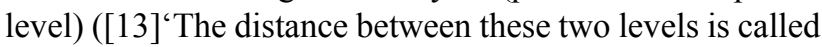
the zone of proximal development'. Vygotsky [12] defines the zone of proximal development as:

'The zone of proximal development...is the distance between actual developmental level as determined by independent problem solving and the level of potential development as determined through problem solving under adult guidance or in collaboration with more capable peers'

One example of the zone of proximal development is an activity that is related to a specific situated activity. It represents a potential for learning created in the interaction between people when engaging in this activity. According to Vygotsky [12], the potential development level describes the level, which towards a child is progressing. Interaction and cooperation with more competent persons are therefore crucial to the appropriation of more advanced ways of thinking and acting.

Appropriation, according to Bråten [14] means that a person learns to be comfortable with physical and intellectual tools in suitable contexts. Appropriation describes the process of taking and borrowing from others and the making it their own[18]. This is a process which develops gradually between people in interaction in joint activities. In this cooperation is the potential for learning and development, which is of key importance. Interaction which takes place through interaction leads to development through this learning. According to Vygotsky [12], mediated learning is, however, something that must be facilitated.

According to Vygotsky [12], teaching in schools must facilitate the development of higher psychological processes by emphasizing the interaction between teacher and pupil, as interaction with others promotes learning and internalization. The zone of proximal development is the zone between the development level the pupil is at and the zone they are moving towards. Hence, the teaching must emphasize starting with the facilitation of social interaction and cooperation between pupils and teachers in teaching. With a little guidance and the support of another with more experience, problems that one would have difficulty solving alone can be solved. Human understanding and development are in continuous development and there are insights and skills which lie beyond the person, which they are moving towards, but still do not fully understand. Help and support are however needed, because the person does not understand well enough to manage alone.

According to Hoel [19], a feeling of security is a condition for success in Internet based communication. This highlights the importance of courses being structured such that students meet physically at an early stage and so build up a joint group culture.

According to Bakhtin et al. [20], human development does not lie in a text or in word, but is created in dialogue between those who participate in the communication. Understanding and the exchange of views is an active process in which the response and reaction of others is an activating principle. There are, according to Bakhtin \& Holquist [20], many voices in a dialogue at the same time. These voices challenge each other, supplement each other or are dialogically related to each other. The different voices, their different perspectives, knowledge, opinions and experience and the tension between them when they meet in confrontation, is a positive contributor to the learning environment. He points, in this theory, to the mutual relationship between those who teach and those 
who listen. He furthermore believes that the facilitation of dialogue in teaching provides the best conditions for learning. He also points to that this type of classroom contains a diversity of different voices and the tension and conflicts which promote creative understanding. The opposite is a classroom that does not provide room for this diversity and in which a teacher-controlled conversation solely transfers knowledge to the pupil. According to Habermas [21], dialogue is a means of reaching agreement on goals and achieving consensus, which in turn eradicates doubt, disagreement, opposition and discussion. According to Bakhtin \& Holquist [20], creative understanding is a key term in the teaching context because creative understanding is founded on knowledge being more than an understanding that can be reproduced and that it arises through dialogue and is stifled by monologue.

We should, according to Bakhtin et.al. [20], strive for dialogue in education. He is also critical of monologue, the exchange of opinion in this being barred and set answers replacing the search for answers. Bakhtin et.al [20] sees monologue as an authoritative discourse that does not provide room for doubt, for searching and objections. Entering into a dialogue using text and with others means that one places oneself in the other's situation and tries out one's own opinion, through which one develops. Mutuality and responsibility to the other are key in all dialogical relationships and being able to understand each other is something one strives for when entering into the context. New opinions and understanding arise in the confrontation between different voices. The goal is not to reach agreement or consensus, but that there are differences in the different voices and that this provides feedback from the other and the grounds for understanding, insight and new knowledge. In a situation where several, different voices are involved we have a dialogue. When there is only one voice, we have a situation with a monologue.

According to Vygotsky [22], there are differences in the language. He differentiates between dialogue and monologue, writing and inner speech describing the monologue, the oral representing dialogue. Vygotsky [22] furthermore claimed that two parties in dialogue must know the subject they are discussing and have a mutual understanding of each other. Dialogue also requires both parties to see each other, see each other's facial expressions and hear their tone of voice. Dialogue is spontaneous and is not formulated in advance. It requires quick responses and replies. Conversely, one has plenty of time to consciously form language in a monologue (Ibid).

Bates [23] assumes that group size is a key factor of success in communication, dialogue and group discussions in teaching on the Internet. This also corresponds with Moore \& Kearsley [24] and Foley in [25] who claim that the number of students in Internet courses will influence dialogue, activity and the distance between student and lecturer. Large groups of students in Internet courses can limit the lecturer's communication and interaction with students, which can, in turn, lead to one-way teaching, few opportunities for discussion and critical questions and students' implicit consent to that teaching/lectures is successful.

According Moore [26], dialogue is developed in the interaction between lecturer and student. 'A dialogue is purposeful, constructive and valued by each party'. Choice of media has a great effect on dialogue. It influences the extent of dialogue between lecturer and student, and transactional distance. It is therefore important that lecturers combine both asynchronous and synchronous communication to minimize transactional distance. Asynchronous communication alone is, however, not enough. It is a form of dialogue. However, combining asynchronous communication with video conferencing makes it more personal and individual and allows the lecturer and student to respond to each other.

Moore's transactional distance theory emphasizes that dialogue and communication are important to succeed with online teaching. Another environmental factors that influences dialogue and transactional distance is the number of students each distant teacher must provide instruction to and the frequency of the opportunity for communication'. More students than the lecturer can relate to often leads to disturbance and hinders dialogue.

To prepare for a useful dialog and interaction in online education, the content, the curriculum, the philosophy of the lecturer and the constraints also need to be taken into account. An example of this is e.g. when a lecturer does not utilize the possibilities that is available. Group work and cooperation with the students could, e.g., easily be facilitated, but is not considered used. The lecturer may not - for various reasons - want to engage with the students in a dialog. It could be linked to the particularities of the course; e.g. a math class may not need the same amount of dialogue as in a course on organizational theory [26].

The theory includes "the universe of teacher-learner relationship that exists when learners and instructor are separately space and/or time" [26]. Moore [26] called these universes that exist between teacher and learner relationship when is separated by space and/or by time for the transactional distance. The transaction that we call, online teaching, occurs between teachers and learners in a context having the special characteristic of separation of teachers from learners. It is this psychological and communication space that is the transactional distance. According to Moore [26] videoconference media will permit a more intensive, more personal and more dynamic dialogue than can be achieved in using a recorded medium. Programs that use audioconference systems are therefore likely to bridge the transactional distance more effectively than programs using recorded media.

In addition to dialogue, Moore also emphasizes structure and autonomy as important components to successful teaching and education. Structure is a measure of the educational program's responsiveness to the learner's 
individual needs and Autonomy describes the extent to which in the learning-teaching relationship, it is the learner rather than the teacher who determines the goals, the learning procedures and resources, and the evaluation decisions of the learning program.

Palloff, R. \& Pratt [27] claim that an experienced lecturer can handle between 20-25 students on the Internet, while an inexperienced lecturer should not teach more than 15 students. No more than 10-12 students should participate in asynchronous meetings and just 4-5 in group discussions [23], [28], [29] furthermore claim that the number of students is critical, that lecturers need training in the efficient use of technology and that team work among lecturers is essential. The choice of medium, however, determines how many students can participate in a course.

Group work will allow the students to learn together with others and learn from each other. This can be compared to what Lave and Wenger [30] call "Communities of Practice" (CoP). The students have a common interest in the curriculum and can learn by contributing with their own experiences, and learn from others and their experiences. There are many ways of forming groups, but the original idea of CoP's was a description of workers with a common interest voluntarily formed groups that learned from each other, often with a peer that had more knowledge than the others. Nowadays, and in an educational setting, the students can either form groups themselves, or be placed in groups. Some students prefer to work on their own, for different reasons. However, all students should be a part of a group as the social part of the learning has proved very important for the total learning outcome [31].

The students in higher education are adult learners. It is thus important to adapt even the online part of the education to support how adult learns. One of the major contributors towards how adults learn is activity [32]. Keeping the students active and also utilize their input towards the education will keep them motivated and engaged, which will enhance the learning outcome [32], [33]. Dewey [34] also suggests to utilize the learners own experiences. To bring the experiences of the students into the education, will offer the students a possibility of reflecting on their own learning from experiencing. This is described by Kolb [35] in his experiential learning cycle which gives an overview of how one can learn from an experience by reflecting upon it, evaluating the learning, expanding on the experience by forming a new experience based on the learning from the previous experience.

The reflection processes this refers to can be expanded by what is described by Schön [36][37] regarding reflecting before an action/experience, during an action/experience and after an action/experience. These reflection processes may be integrated in the blended learning, not only in the face-to-face seminars, but also adapted in the online part of the education, e.g. through assignments.
Another part of the online learning environment is advising. Advising requires trust, something that requires experience and cooperation. The advising can be done synchronous (via e.g. Skype) or asynchronous (e.g. e-mail). Synchronous via e.g. Skype, offers a partial picture of the «reality», hence a slightly lesser offer rather than face-to-face. However, for remote students the time spent on studying rather than travelling, is welcomed.

According to Jamissen [38] students who choose to study online will be different from the Campus student because it is primarily for the web student that it is primarily competence enhancement or continuing education. The students usually combine education with work and family life. Therefore, flexibility will be important in online education.

According to Hjertø, Fjeldavli, Munkvold, \& Hole [39], asynchronous communication will be preferable because of the flexibility inherent in this type of communication because synchronous communication requires students to present in teaching.

Flexibility is defined as how information and communication technology in teaching and dissemination provides increased flexibility and accessibility by making less education dependent on time and place. According to Ballo [40], flexibility will concern increased availability in relation to time and place of study.

According to Lynch [41], good structure in a flexible web-based subject will be a critical factor and a prerequisite for success in online-based education. But, at the same time, it becomes important for lecturers to balance between flexibility and structure adapted to the student studying online.

The online situation regarding advising requires that trust; trust regarding the competence and capabilities [42]. A personal meeting in the start of the semester may establish this trust, rather than spending several online meetings to obtain the same level of trust, as it is then possible to meet up, become acquainted, test the gear used for the advising, etc. This will enhance the personal mastery [43] within the advising session.

Another aspect is that there may be a difference between what is seen and what is intended, and the interpretation is colored by one's own perspective. Previous experience will also have implication. If, for instance, the student has previously negative experience, this may influence the way the students approach the online advising, mostly in a negative way. Literature on teambuilding supports the idea of the physical meeting in the beginning of a study in order to establish the necessary trust and confidence building [44].

\section{Method of Inquiry}

The data material presented in this paper is collected by studying the online teaching in two different university 
colleges in Norway. The research project is developed as a case-study design. The approach is mainly qualitative, by using a combination of methods such as observation and interviews, both structured and semi-structured [45]-[47]. The structured interviews have been conducted by following an interview-guide with predefined categories. But by combining the structured and semi-structured interview approach, the researcher has made it possible to catch up unforeseen matters that emerge during the conversations.

As is common in case-studies, the categories are theory-based, making this a deductive approach. The data are analyzed by a software system for analyzing qualitative data. (Atlas). The use of triangulation of methods secures multiple sources of data, and gives a better accuracy of understanding when collecting and analyzing data [48].

This research chooses to use qualitative interviews of 13 lecturers who teach online. In addition to the 13 lecturers who were interviewed, five lectures were observed in online education. We would like to first and foremost interview the lecturers who teach online and then see how they teach online practice.

The online students are both full-time and part-time students. The lecturers interviewed teach in Professional Studies, Secondary Education for Teachers and Others, Basic Studies in Education, ICT and Learning (Economic Education), Bachelor of Information Systems, Consulting, Social Education for Teachers and Others, Undergraduate Studies in Education, Digital Media and Formation Master.

This research is based on the lecturer's subjective experiences and perspectives on teaching online. These are conditions that must be presented for communication, dialogue and inter-school with the students in online education.

The research has chosen a case study design because it has strategically been chosen for two colleges that engage in online education. The purpose of this choice is to get complementary information about a delimited phenomenon in combination with the methods of interview and observation.

Theory and research on online education has been used to find theoretical quality indicators that are then used in a semi-structured interview guide and an observation form. The chosen theory and assumptions have acted as a tool for creating theoretical indicators such as; group size, recording of lectures real-time education online / seminar communication and online dialogue (asynchronous / synchronous communication).

Through the selected informants at these two colleges, the dissertation will develop new and more knowledge of online education. The purpose is to increase knowledge of online education by explaining and understanding these lecturers' practices online in the background of theory.

By using multiple data sources, it opens up to capture diversity, different views, different angles and complexity of a phenomenon, and this will be achieved by using qualitative interviews in combination with observation. These methods will provide a more comprehensive and comprehensive illumination of the phenomena being studied.

Prior to the interviews, a semi structured interview guide was prepared based on the theoretical framework with categorizations/topics as main questions. Each theme also had questionnaires.

The interview guide was thematized with regard to its relevance to the thesis and issue of the thesis. Themes and concepts like; group size, communication, dialogue, seminars, videoconferencing, physically mandatory on-campus seminars content on the physical compulsory seminars, real-time teaching and admission to teaching or not derived from relevant theory.

This research has chosen to use a deductive approach because it is based on theory which in turn is the background for the problem of empirical research. A data collection was conducted to apply selected and relevant theory to the data to understand and explain what is being studied.

When understanding the lecturers' own perspectives, experiences, success criteria and challenges about teaching online based on the data material and based on a deductive approach it will mean that interpreters must interpret the interpreters. To interpret an already interpreted reality, Anthony Giddens refers to double hermeneutics [49]. The analysis assumes an interpretation of the informants' own understanding of what they do and how they do it in online education. It becomes important to establish a connection between selected theory and concepts and the terms used by the informants to interpret what they experience. It is not enough to describe the informants' perceptions and descriptions, but we must use social science concepts to reproduce the informants' perceptions, which in turn will go beyond the informants' self-conceptions. It is about integrating informant's experience-intensive concepts (what they say about what they think and experience) with experiential concepts (social science theory and concepts) [50].

After the transcriber of all data material, meaning categorization was used. That is, the interview is categorized in categories[51], [52]. Long statements are reduced to simple categories that can indicate the occurrence or absence of the phenomenon [53]. Categorization of the data will also say that information about the same theme is collected in one category [54].

Interpretation of opinions is about making sense of the data material [5]. Furthermore, it is about how to understand the relationships and patterns that one has found. Interpretations must be rooted in the patterns and contexts that the data represents [54]. It is important to balance themselves interpretation and the description that the informants have conveyed. The research is looking for the informants' interpretations of the phenomena and what they experience and experience what are the conditions for 
success in online education. It will be their interpretations that are the basis of the analysis and their experiences, experiences, success criteria and challenges about what the meaning of the phenomenon gives them. The next level will be to draw in the researcher's theorizations.

\subsection{Doing Research on One's Own Profession}

Doing research on one's own field of expertise can be a daunting task. We aim to offer contributions to the research in the field of education. The lecturers that are the informants in this study have much the same background as the authors of this article. This enables the dialogue to be about the research objective, rather than spending time on getting to a mutual understanding. According to Gadamer [55], this understanding is a possibility of common grounds regarding knowledge. To be able to ask the relevant questions it is important to know about the theoretical paradigm [56]. By knowing the field it is possible to bring forward relevant knowledge and it enhances the validity and reliability [57].

At the same time, the researcher must be aware about not being close to the field so that one can avoid analytical obstacles. It was at times challenges with creating the right distance to the research topic. Several assumptions that we had made in beforehand were dismissed during the research process. According to Volckmar [58], researchers in qualitative research may become too close to their material and thus not be able to maintain the critical distance needed. Hence, the analysis and findings will confirm the assumptions [57]. To prevent getting too close to the study objects, we have chosen informants that teach in vocational education and that represent different areas of expertise, than what we represent.

\section{Results and Analysis}

Here we will present our results from the research and our analysis of the data. The university colleges discussed in this paper are examples of university colleges that offer different types of courses on the Internet.

The main findings of this research are that these lecturers conduct online education through three different online Web net models. These three online web net models in online teaching combine asynchronous and synchronous communication and facilitate different levels of activity, engagement, dialogue and communication in online education. These models vary with the aim of facilitating the flexibility of online students that combine work and study.

\section{Three Different Online Web Net models}

Model 1 uses asynchronous communications without mandatory presence. Internet based course in which both recordings of lectures, assignments and guidelines are made is available to students on the Internet. This model allows students to study at a place and time of their choice. Lecturers and students have no fixed meeting points in real time. Students are required to receive tutoring, but can influence when and how tutoring takes place. Tutoring can take place via email, Fronter or by the lecturer and student meeting in a virtual space on the Internet. The lecturer encourages the students to work together in groups on the Internet via Forum, Google Messenger, and Adobe Connect etc.

In this model, students have a large degree of flexibility because they can study independently of time and place while combining work and study.

According to Bakhtin [20][1], this kind of teaching will be a type of monologue and an authoritative interpretation because lectures are read on tape to students without discussing content with the students. In model 1, the authoritative word will dominate because it closes for doubts, discussions and oppositions. According to Vygotsky [22], written and inner speech will describe the monologue. According to Bakhtin [59], this will be a room or education that does not allow for creative comprehension and diversity, but a teacher-driven conversation that transfers knowledge to the student. This can also describe model 1.

Social meeting places are absent in Network model 1 because this context adds to all teaching conducted through asynchronous communication. That is, lectures are read on tape. According to Moore [26], a video lecture that is read on tape will be very structured. There will be no opportunities for the students to influence this content. Moore [26] assumes that by combining admission to meeting the students in a video conference there will be more room for dialogue and less structure. According to Moore [60], media choice will have a major impact on the dialogue. This will help increase the distance between lecturers and students. By using only asynchronous communication, the dialogue will be absent between students and lecturers.

Model 2 is another type of internet-based course that combines asynchronous and synchronous communication with lectures in real time. Lecturers and students communicate using a video conferencing system with chat, which allows students and lecturers to communicate during lectures. Lecturers and students are therefore connected through the video conferencing system and can communicate using a camera and microphone. The internet-based courses at these two university colleges provide decentralized teaching on the internet and on campus seminars and are therefore included in the definition flexible education.

The hybrid model uses a hybrid format. In this, the lecturer lectures both to students on Campus and to students on the internet at the same time. The lecturer communicates face to face with students in the lecture room on campus, but is separated by time and space from the students in virtual rooms all around the country, at their study centre or at home. It has been decided that no more 
than 50 students are to attend lectures on the Internet for this type of course, to avoid hindering activity and communication.

The university colleges use Fronter as a communication tool for communication between teacher and student. Fronter can be considered to be an Internet based learning arena and a learning management system (LMS). It has public chat rooms, group rooms and private chat rooms. Students can submit written assignments via Fronter and receive feedback on assignments from lecturers via the system. Students can exchange their experiences in group rooms and discuss academic problems in writing. The university colleges use the OmniJoin video conferencing system which has a built-in Chat system

The two types of web net models which use both asynchronous and synchronous communication include an obligatory four-five day on campus seminars which all students are required to attend. This is always held before the start of an internet course. The aim of this obligatory on campus seminars is for students and the lecturer to get to know each other, to provide an introduction to the subject they are going to be studying on the Internet, to provide training in video conferencing, in Webinar, chat and fronter, to provide training on how to use the library when studying on the Internet, to attend a writing course and to divide the students into groups for working together on the Internet and for social events such as dinners. The aim of the gathering is also to become comfortable with each other and to receive the training which is required to study on the internet. After the gathering, the lecturer and students meet on the Internet. These two types of internet-based courses always run in real time, so that the students have the opportunity to interact and communicate with the lecturer and with each other. Communication, dialogue, guidance and interaction are via the Omnijoin with chat video conferencing system.

Compulsory on campus seminar before a start with online education can match the Salmon e-learning model (3) which has a five-step model describing the different steps that students and lecturers need to implement or who must be present to engage the students in online education. In step 1, lecturers will ensure that students have access to online tools and training on these tools will be given. The students who attend the compulsory physical seminar receive all the necessary training on technology before they start up with online education. In step 2 of Salmon's e-learning model, lecturers will facilitate collaboration and interaction between students and between lecturers and students. These lecturers are concerned that the students get to know each other, and that the students should be active in discussions, have dialogue and communication. This also complies with Salmon's e-Learning model step 3.

In model 2 and in the hybrid model, there is a clear and solid structure of formalized expectations, as the student is required to meet up on these physical meetings but, in turn, can inhibit the student's flexibility by perhaps having to travel far to these on campus seminars and that these seminars may lead to additional costs. In addition, this practice can help to inhibit the students' flexibility by not studying independently of time and place. Students have no or no opportunity to deviate from a planned education program and there is little flexibility built into the teaching methods that are added to these on campus seminar.

According to Flate Paulsen [6], the number of physical meetings should be reduced to a minimum, allowing students to study independently of time and place and be more flexible.

\section{On-campus Seminars}

Both colleges that have been studied organize two or more compulsory physical on-campus seminars, one before and one during the semester. On-campus seminars include activities such as introduction to technology, writing courses, getting to know the library, administrative information, group establishment, group work, individual conversations, and behavioral knowledge in real time use, lecturing, social dinners and other social activities. The purpose of these seminars is to become better acquainted and to promote good relations between the students. This is considered a key factor to success as this will make it easier for the students to be active and engaged during lectures and seminars.

This use of on-campus seminars is a good example of blended learning as it combines physical seminars with online teaching. It is furthermore in accordance with Salmon's five stage model [4] as it provides support to the students and promotes active participation.

According to Vygotsky [22], language is a communication tool that allows communication with others and the sharing of experiences with others, which in turn leads to knowledge building. Vygotsky furthermore claimed that the language of thought and external speech in social interaction is called dialogue (external). Interacting with others and hearing others' experiences allows us to build up knowledge, the language of thought being made private. Knowledge that has been incorporated into the individual and become private is called monologue (inner). This also partly corresponds with Bakhtin \& Holquist [20], who claimed that creative understanding is about dialogue, understanding, confrontation with different voices, understanding each other, discussing, learning from each other, giving feedback to each other and is where different perspectives meet. This promotes creative understanding and is a positive contribution to the learning environment. It also provides the individual with opinion and understanding and is what creates knowledge. The opposite is authoritative discourse, which is a classroom in which there is no room for different voices, confrontation, doubt and the search for knowledge, a more teacher-controlled conversation, a reproduction of knowledge and a set answer and a monologue. Vygotsky [22] claims that 
monologue involves a written and inner speech while dialogue is oral speech in which one should see each other's facial expression and hear each other's tone of voice. Dialogue is spontaneous and is not formulated in advance.

The two models use both asynchronous and synchronous communication and are focused on social interaction, becoming comfortable in using cultural tools, communicating with students and lecturers and on activity. These types of internet-based teaching are focused on ensuring students are comfortable with studying on the Internet and are comfortable and familiar with the other students and the lecturers, so that they feel secure when communicating on the Internet. This is achieved by arranging physical obligatory gatherings to provide training to the individual student in how to handle technology and how to study on the Internet and by ensuring student groups in teaching are not too large and by teaching in real time. They communicate through technology. So, this is also about being comfortable with the technology which is used in this teaching. Lecturers are focused on not making recordings of teaching, because they want to talk to students in lectures and construct knowledge in real time, even though they are teaching facts. Lecturers ideally should hold a lecture prior to group work. Students will then have the opportunity to communicate during the lecture with the lecturers using a video conferencing system with built in Chat. These lecturers are also focused on students being active and involved in the lectures, so that good communication is achieved. This corresponds with both Bakhtin's [20] creative understanding and Vygotsky's [22] external speech. The last type of Internet based teaching, which only uses asynchronous communication, corresponds more with Bakhtin's [20] authoritative discourse, where only recordings of lectures are used and little emphasis is placed on interaction between lecturer and students.

\section{Group Size}

The number of students in the individual online lecture is also a considered a critical factor. Bates [23] assumes that the size of classes involved in online education and the number of overall students involved are key factors in order to succeed with communication, dialog, activity and group discussions. According to M. Moore [26], the number of students is one of the environmental factors that will influence dialogue, activity and the transactional distance between teacher and learner. Large student groups being lectured online may inhibit the lectures interactivity with the students, which might cause more one-way lectures without possibility of discussions, confrontations and critical questions. Foley [61] presumes that group size or number of students online is a critical factor regarding the importance of communication, interaction and discussions. Palloff and Pratt[27] claim that an experience teacher might handle between 20-25 students online whilst an unexperienced might handle only 15 . Research shows that both quantity and quality interaction with the lecturer is a critical factor for success in online lecture [62]. In accordance to Palloff and Pratt [27], they recommend having no more than 10 students whilst lecturing online because of the plausible confusions and inhibit communication with so many students simultaneously.

Both colleges have chosen relatively small groups of students for their online lectures and the individual groups vary between 10 and 50 . The teachers that have up to fifty students online argue that it is too many to handle. They argue that the presence of the conversation and activity disappear and that the lecturing becomes mechanical and monologue when they have these many students.

Vygotsky \& Kozulin [17] used the term zone of proximal development as a place where a person, through interaction with others with more experience, acquires new knowledge. There is a distance between what you can manage alone without help, and what you can achieve with another's guidance, or in cooperation with others who have more knowledge. For example, the two Internet based types that use physical obligatory gatherings prior to teaching on the Internet is a specific situated activity. Students are required to physically attend on Campus. All students who are to study on the Internet meet on Campus and receive the training they need to be able to study on the Internet. They receive training in cultural tools such as training in the technology and training in how to study on the Internet. They also learn different ways to interact. This teaching and development is rooted in social activities, which then are converted to knowledge and understanding in the individual. Training is given in the cultural tools together with others at the physical obligatory gatherings on Campus. Facilitating social interaction with others in teaching means that the individual reflects upon their own everyday terms and acquires new scientific terms in social interaction. Lecturers facilitate the activities which are crucial to being able to study on the Internet, students receiving training in the technology (physical tool) receiving it from others who have the knowledge needed to be able to study on the Internet. Training on Campus is crucial to the appropriation of more advanced ways of thinking and acting, which students then make their own understanding. The physical obligatory gathering therefore involves becoming familiar with the physical and intellectual tools in suitable contexts.

The socio-cultural learning perspective assumes that learning and knowledge development take place through communication and interaction with others. A key factor in Internet teaching in the facilitation of interaction, dialogue and communication is, Bates [23] claimed group size. The two types of Internet based teaching which use asynchronous and synchronous communication focus on restraining class sizes to no more than 50 students in the Internet classroom. This also corresponds with Moore, who claimed that successful dialogue and communication on 
the Internet requires class sizes that are not too large, as this influences dialogue, activity and the transactional distance between students and lecturers. Student groups that are too large increase transactional distance and reduce dialogue. Moore furthermore claimed that choice of media greatly affects dialogue and activity in teaching on the Internet. Combining asynchronous and synchronous communication, however, minimizes transactional distance. This corresponds with the two types of Internet based teaching which combine obligatory physical gatherings with teaching in real time on the Internet. Moore furthermore claimed that it is not enough to use asynchronous communication in teaching on the Internet. Asynchronous communication should also be combined with video conferencing to make dialogue more personal and individual. This corresponds with one of the types of Internet based teaching which only uses asynchronous communication and in which students and lecturers has no fixed meeting point in real time.

\section{Teaching in Real Time}

The research shows that teaching in real time is the dominant way of teaching at both colleges. Each online teaching session might last up to eight hours and includes activities like tutoring, group work, and lectures. In addition to this, individual online tutoring sessions are also available for the students and cooperation between the students is highly recommended.

In this regard, both colleges from our study has responded to individual students needs which is according to what Moore [26] promotes in the structure part of his transactional distance theory. By choosing teaching in real time, the colleges are also acting according to the recommendations from Hratstinski [63]. He argues that taped lectures is far less effective as this does not take into consideration the students' experiences, competencies, and requirements.

Another type of Internet based course is solely Internet based. The lecturer lectures on Campus in an electronic lecture room which is equipped with video conferencing equipment. No students are present. The lecturer communicates solely through the video conferencing system with students who either are at a study centre or at home. This type also uses asynchronous and synchronous communication. The lecturer is separated in time and space from the students. It has been decided that no more than 50 students are to attend lectures on the Internet for this type of course, to avoid hindering activity and communication.

According to Vygotsky \& Kozulin [17], language is a communication tool that allows communication with others and the sharing of experiences with others, which in turn leads to knowledge building. Vygotsky furthermore claimed that the language of thought and external speech in social interaction is called dialogue (external). Interacting with others and hearing others' experiences allows us to build up knowledge, the language of thought being made private. Knowledge that has been incorporated into the individual and become private is called monologue (inner). This also partly corresponds with Bakhtin \& Holmquist [20] who claimed that creative understanding is about dialogue, understanding, confrontation with different voices, understanding each other, discussing, learning from each other, giving feedback to each other and is where different perspectives meet. This promotes creative understanding and is a positive contribution to the learning environment. It also provides the individual with opinion and understanding and is what creates knowledge. The opposite is authoritative discourse, which is a classroom in which there is no room for different voices, confrontation, doubt and the search for knowledge, a more teacher-controlled conversation, a reproduction of knowledge and a set answer and a monologue. Vygotsky \& Kozulin [17] claimed that monologue involves a written and inner speech while dialogue is oral speech in which one should see each other's facial expression and hear each other's tone of voice. Dialogue is spontaneous and is not formulated in advance.

\section{Conclusions}

Our conclusion is that not only do the students need to work together and that the size of the group will have an impact on the learning outcome, but most important is the personal meeting in the start of the total learning activity. The personal meeting will contribute towards the total learning outcome of the educational activity as the meeting with fellow students, and the faculty staff, will reduce the distance and gap between the parties. It will support the advising process as the introductory phase may be done face to face and thus lay the ground for an improved mutual understanding in the advising process. Also, the meeting with peers may lower the threshold for reaching out to fellow students either for cooperation or help.

In model 2 and the hybrid network model the lecturers utilize limitation of group size, mandatory campus seminars, video conferencing with chat and real-time education without recordings. These models use both asynchronous and synchronous communication and add up to a teaching that emphasizes dialogue and communication between lecturers and students. However, at the same time, these two models are less flexible than model 1 because students cannot study independently of time and place because of compulsory campus seminars, as well as real-time lessons once a week and lack of recordings of lectures.

Model 1 uses asynchronous communication. Group size, real-time teaching, video conferencing with chat compulsory seminars on campus, dialogue and communication are not prerequisite for learning online in this model. Model 1 is more flexible because students to a 
larger degree are left to themselves and can decide when to study.

Our research indicates that all three models could be improved. Model 2 and the hybrid model would become more flexible if they combined teaching with recorded lectures and to a larger extent consider attendance in classroom teaching voluntary. Model 1 could improve dialogue and communications if they combined recorded lectures with voluntary seminars with lecturers.

\subsection{Future Research}

This is a part of an ongoing research and more results will be available from different projects, some of them as a result of blended learning, and some with only online learning activities. Also, it will be interesting to test out the effect of a face to face meeting in the middle of a semester/course, and how this will affect the learning outcome.

\section{REFERENCES}

[1] W. Xing, X. Chen, J. Stein, and M. Marcinkowski, "Temporal predication of dropouts in MOOCs: Reaching the low hanging fruit through stacking generalization," Comput. Human Behav., vol. 58, pp. 119-129, 2016.

[2] N. Deschacht and K. Goeman, "The effect of blended learning on course persistence and performance of adult learners: A difference-in-differences analysis. (Report) (Author abstract)," vol. 87, p. 83, 2015.

[3] G. Salmon, E-moderating : the key to teaching and learning online, 3rd ed. New York: Routledge, 2011.

[4] G. Salmon, E-tivities: the key to active online learning. London: Kogan Page, 2002.

[5] A. K. Larsen, En enklere metode: veiledning $i$ samfunnsvitenskapelig forskningsmetode, 2. utg. Bergen: Fagbokforl., 2017.

[6] M. F. Paulsen, "Online education systems: Discussion and definition of terms," NKI Distance Educ., vol. 202, 2002.

[7] R. Säljö, Lärande i praktiken : ett sociokulturellt perspektiv, 2. uppl. Stockholm: Prisma, 2000.

[8] R. Säljö, "Learning as the use of tools: a sociocultural perspective on the human-technology link," in Learning with computers, Routledge, 2002, pp. 158-175.

[9] R. Säljö and S. Moen, Lcering i praksis : et sosiokulturelt perspektiv. Oslo: Cappelen akademisk, 2001.

[10] J. V Wertsch, Vygotsky and the social formation of mind. Harvard University Press, 1985.

[11] J. V Wertsch and G. R. Semin, Voices of the mind: a sociocultural approach to mediated action. Cambridge, Mass: Harvard University Press, 1991.

[12] L. S. Vygotsky, Mind and society: The development of higher mental processes. Cambridge, MA: Harvard University Press, 1978.

[13] L. Vygotskij and A. Kozulin, Tenkning og tale. Gyldendal Akademisk, 2001.

[14] I. Bråten, Laring : i sosialt, kognitivt og sosialt-kognitivt perspektiv. Oslo: Cappelen akademisk forl., 2002.

[15] J. Bliss, R. Säljö, and P. Light, Learning sites : social and technological resources for learning. Amsterdam: Pergamon, 1999.

[16] I. Bråten, Ed., Vygotsky i pedagogikken. Oslo: Cappelen akademisk forl. oslo, 1996.

[17] L. S. Vygotskij and A. Kozulin, Thought and language. Cambridge, Mass: MIT Press, 1986.

[18] J. V Wertsch, Mind as action. Cambridge, MA: Harvard University Press, 1998.

[19] T. L. Hoel, Kent Adelmann: Att lyssna till röster : ett vidgat lyssnandebegrepp $i$ ett didaktiskt perspektiv. Mölndal: Institutionen för pedagogik, Göteborgs universitet, 2003.

[20] M. M. Bakhtin and M. Holquist, "The dialogic imagination : four essays," vol. no. 1. University of Texas Press, Austin, 1981.

[21] J. Habermas, The theory of communication Action. London: Beacon Press, 1981.

[22] L. S. Vygotsky, "Thought and language." Cambridge, ma: mit Press, 1986.

[23] T. Bates, Technology, e-learning and distance education. London: Routledge, 1995.

[24] M. G. Moore and G. Kearsley, Distance education : a systems view of online learning, 3rd ed. Belmont, Calif: Wadsworth, 2012.

[25] M. G. Moore and W. G. Anderson, Handbook of distance education. Mahwah, N.J. Erlbaum, 2003.

[26] M. Moore, Theory of transactional distance. In: KEEGAN, D. (ed.) Theoretical Principles of Distance Education. Routledge, 1997.

[27] R. M. Palloff and K. Pratt, The virtual student : a profile and guide to working with online learners. San Francisco: Jossey-Bass, 2003.

[28] D. E. Hanna, M. Glowacki-Dudka, and S. Conceição-Runlee, 147 practical tips for teaching online groups : essentials of Web-based education. Madison, Wis: Atwood Publ., 2000.

[29] J. Foreman, "Distance learning and synchronous interaction. The technology Source.," 2003.

[30] J. Lave and E. Wenger, Situated learning - Legitimate peripheral participation. Cambridge: Cambridge University Press, 1991.

[31] H. M. Haave, A. S. Hole, and T. Vold, "Educating Managers in Knowledge Intensive Organizations.” 2016.

[32] J. Rogers, Adults learning, 5th ed. Maidenhead: Open University Press, 2007. 
[33] D. F. Monk, "John Dewey and Adult Learning in Museums," Adult Learn., vol. 24, no. 2, pp. 63-71, 2013.

[34] J. Dewey, Democracy and education: an introduction to the philosophy of education. [Champaign, Ill.]: [Book Jungle], 2008.

[35] D. A. Kolb, Experiential learning: experience as the source of learning and development. Englewood Cliffs, N.J.: Prentice-Hall, 1984.

[36] D. A. Schön, Educating the reflective practitioner. San Francisco, Calif.: Jossey-Bass, 1987.

[37] D. A. Schön, The reflective practitioner : how professionals think in action. Aldershot: Avesbury, 1991.

[38] G. Jamissen, "Nettstudenter er forbløffende like alle andre studenter," Refleksjoner etter en periode som nettstudent ved open Univ. i Alexandersen m. fl.(2001) Nettbasert laering $i$ høgere utdanning, SOFF-rapport, no. 1, 2001.

[39] G. Hjertø, A. Fjeldavli, R. Munkvold, and G. O. Hole, Nettbasert undervisning. Kristiansand: Høyskoleforl., 2008.

[40] Ø. Ballo, "Fjernundervisning i grunnutdanning for allmennlærere : sluttrapport fra et SOFF-støttet prosjekt," vol. 5-2006. Eureka forlag, 2006.

[41] M. Lynch, A guide to effective school leadership theories. Routledge, 2012.

[42] S. Holen, O. J. S. Ranglund, L. V. Kiønig, and T. Vold, "KM Strategies Taught for Crisis Preparedness." Academic Conferences and Publishing International, 2016.

[43] P. M. Senge, The fifth discipline : the art and practice of the learning organization. London: Century Business, 1992.

[44] K. B. Hjertø, Team. Bergen: Fagbokforl., 2013.

[45] M. Dalen, Intervju som forskningsmetode. Oslo: Universitetsforl., 2011.

[46] N. K. Denzin and Y. S. Lincoln, The Sage handbook of qualitative research. Thousand Oaks, Calif.: Sage, 2005.

[47] A. Strauss and J. Corbin, Basics of Qualitative Research Grounded Theory Proceduresand Techniques. Newbury Park, California: Sage Publications, Inc., 1990.

[48] Y. S. Lincolm and E. . Guba, Naturalistic Inquiry. Sage, 1985.

[49] A. Giddens, "Sociology. London: Polity," 1997.
[50] C. Geertz, "Thick description: Toward an interpretive theory of culture. The interpretation of cultures: Selected essays (pp. 3-30)," New York, NY Basic, 1973.

[51] S. Kvale and S. Brinkmann, Det kvalitative forskningsintervju, 2. utg. Oslo: Gyldendal akademisk, 2009.

[52] S. Kvale and S. Brinkmann, Det kvalitative forskningsintervju, 3. utg., 2. Oslo: Gyldendal akademisk, 2015.

[53] A. Johannessen, L. Christoffersen, and P. A. Tufte, Forskningsmetode for økonomisk-administrative fag, 2. utg. Oslo: Abstrakt forl., 2004.

[54] T. Thagaard, Systematikk og innlevelse, vol. 2. Fagbokforlaget Bergen, 1998.

[55] H.-G. Gadamer and L. Holm-Hansen, Sannhet og metode: grunntrekk $i$ en filosofisk hermeneutikk. Oslo: Pax, 2010.

[56] T. S. Kuhn, The structure of scientific revolutions, 2 nd ed., E., vol. 2.2. Chicago: University of Chicago Press, 1970.

[57] T.-A. Skrefsrud and S. Østberg, "Diversitet i lærerutdanningene-bidrag til en profesjonsorientert forståelse av fag og kunnskapsområder," Nor. Pedagog. Tidsskr., vol. 99, no. 3-4, pp. 208-219, 2015.

[58] N. Volckmar, "Fra solidarisk samværskultur til kunnskapssolidaritet. Det sosialdemokratiske skoleprosjekt fra Sivertsen til Hernes," Norges teknisk-naturvitenskapelige universitet, NTNU, Trondheim, Norge, 2004.

[59] M. Bakhtin, "The aesthetics of verbal creation," Moscow: Bocharov, 1979.

[60] G. Moore, M.G.,\& Kearsley, Distance education: A system view of online learning, Third edit. Wadsworth, Centage Learning, 2012.

[61] . Foley, The Global development learning network: A World Bank initiative in distance learning for development. Lawrence Erlbaum Associates., 2003.

[62] P. Woods, "Teaching and Learning in the New Millenium," in Developing teachers and teaching practice: international research perspectives, C. Sugrue, C. Day, T. International Study Association on, and Teaching, Eds. London; New York: Routledge/Falmer, 2002.

[63] S. Hrastinski, Nätbaserad utbildning: en introduktion. Lund: Studentlitteratur, 2009. 